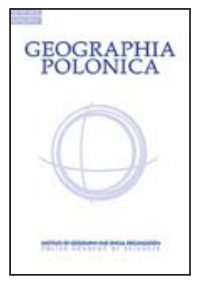

\title{
AIR TEMPERATURE AND LOCATION OF ISOBARIC SURFACES IN RELATION TO ATMOSPHERIC CIRCULATION, BASED ON RADIOSONDE DATA FROM LEGIONOWO, POLAND
}

\author{
Grzegorz Urban (D) - Michał K. Kowalewski \\ Institute of Meteorology and Water Management - National Research Institute \\ Podleśna 61, 01-673 Warsaw: Poland \\ e-mails: Grzegorz.Urban@imgw.pl • Michal.Kowalewski@imgw.pl
}

\begin{abstract}
This paper analyses the changes of temperature at the ground-level and the temperature and location of the selected isobaric surfaces in relation to Lityński atmospheric circulation (1969) as modified by PiankoKluczyńska (2007). The basic data used in this paper were everyday radiosonde measurements obtained from the Aerological Station in Legionowo in the years 2001-2010 at 00 UTC. The subject of the analysis were yearly and seasonal average temperatures as well as the locations of isobaric surfaces. The biggest differences between isobaric surfaces locations during anticyclonic kinds of circulation and those during cyclonic ones occur in winter, while the smallest such differences appear since May till September. When analysing the circulation type (direction and kind), it was established that isobaric surfaces are located at the lowest level during circulations from the northern quadrant. The universality of the circulation calendar which was used and the geographical location of the Aerological Station in Legionowo entitle us to claim the results of this study to be representative for the lowland of Central Europe.
\end{abstract}

\section{Key words}

radiosonde data - isobaric surface - atmospheric circulation - air temperature - Central Europe lowland

\section{Introduction}

Temperature changes both on the ground and in the upper strata of troposphere are conditioned by, among other factors, atmospheric circulation and the circulation-related advection of air masses. Atmospheric circulation is the main factor determining the inflow of air masses that shape the weather and climate of a given region. (Niedźwiedź 1981, 2000; Buishand \& Brandsma 1997; Plaut \& Simonnet 2001; Kyselý 2002; Sepp \& Jaagus 2002; Kyselý \& Huth 2006; Huth et al. 2008; Ustrnul et al. 2014). The issue of advection's influence on the temperature of air in the lower and middle layers of troposphere 
has been subject of many studies (Renard \& Clark 1965; Strauch 1974; Hill \& Simpson 1989; Kożuchowski et al. 1992; Wibig 1994, 2001; Plaut \& Simonnet 2001; Marshall 2002; Sepp \& Jaagus 2002; Bakowski 2003, 2007; Wibig et al. 2009a,b; Tomczyk \& Bednorz 2016, Tomczyk et al. 2018). The strong seasonal diversification of mid-tropospheric circulation's impact on temperature was proved by the analysis of the correlation of average temperature in Poland and the values of $500 \mathrm{hPa}$ geopotential height value (Wibig 1994). Similarly, Degirmendžić and Kożuchowski (2017) emphasised the influence of the circulation in the upper troposphere on the pressure field and dynamics of lower pressure systems, in particular - on the directions and intensity of advections and the advective changes in ground-level air, including its temperature. These authors proved evident relationships between thermal conditions in free atmosphere and those on ground level. However, these relationships vary depending on the location of the study area (Pyka 1990; Kowalewski 2003; Marshall 2002) and on the studied tropospheric layer (Japan Meteorological Agency 1988).

The aim of this study has been to determine changes in the ground-level air as well as the temperature and location of the selected isobaric surfaces in relation both to the type of atmospheric circulation and the particular parameters of ground-level air (kind and direction). Moreover, the relationship between the temperature of ground-level air and that of the selected isobaric surfaces has been analysed.

\section{Source data and methods}

The basic data used in this paper were everyday radiosonde measurements obtained from the Aerological Station of the Institute of Meteorology and Water Management - National Research Institute (IMGW-PIB) in Legionowo (96 m a.s.l., $\phi 52^{\circ} 24^{\prime} \mathrm{N}, \lambda 20^{\circ} 57^{\prime}$ E) in the years $2001-2010$ at 00 UTC. The choice of night radio sounding allowed for the elimination of sunlight impact on the results. The location and temperature of four main isobaric surfaces within troposphere: $925 \mathrm{hPa}, 850 \mathrm{hPa}, 700 \mathrm{hPa}$ and $500 \mathrm{hPa}$ were analysed. It is on these isobaric surfaces that the advection of air masses exerts its influence. Whereas the choice of the 20012010 multiannual period resulted from the fact that during that time the radiosonde data were the least incomplete and obtained with the use of the radiosondes types which did not differ significantly. In the period under study, only 56 out of 3652 potential measurement records were missing. They referred to singular days over different months and years. The missing records were not replaced or estimated but excluded from the analyses.

Despite merely 10-year's period under analysis, it might be assumed that the obtained results are representative for the assessment of temperature conditions on particular isobaric surfaces. Such approach complies with the generally accepted view that average ten-year values of particular meteorological elements depict the characteristics of climate spatial diversification and gives the opportunity to discover the general laws governing a given phenomenon (Hess 1965; Hess et al. 1980). According to other authors, the optimal period for reliably determining mean air temperature for a station that has a data series significantly shorter than 30 years ranges from 5 to 15 years (Huang et al. 1996). Huang et al. (1996) stated that if mean values are to be determined, the exact length of the period adopted for this purpose within the 10-30-year range is not significant. This view finds its confirmation in, inter alias, the results obtained for the winter thermal severity index in the Western Sudetes (Urban et al. 2018).

During the 2001-2010 multiannual period the following types of Vaisala radiosondes were used: RS-80 and RS-90 (2001-2003), RS-92 and RS-92-KL (since 2004). They were attached to a balloon filled with hydrogen. The sondes introduced in 2004 differed from their predecessors with respect to the casing and electronic solutions. RS-92 sondes feature inscribed factory calibration coefficients, 
which eliminated the necessity of manually introducing earlier models to a system. In 2005 Polish aerological stations were equipped with DigiCora MW21 systems, which enable GPS navigation tracking, and these are in use till today (Biszczuk-Jakubowska \& Zabłocki 2015). All radio sounding systems and all types of sondes require authorisation by World Meteorological Organization (WMO). The authors of the study recognized the changes in the sondes that are mentioned above as insignificant for the obtained results and they considered measurement material used to be homogenous.

Regardless of the duration of the radio sounding and horizontal movement of the balloon, the results of the soundings refer to the vertical space in the atmosphere above the station and to the time at which the sounding was made. The starting data: atmospheric pressure, air temperature and relative humidity, come from the Stevenson screen near the starting field (Ordakowski et al. 2000). Air temperature values at the start of the sonde were used and they were measured in the Stevenson screen at a height of 2 metres above ground level according to the standards of National Hydrological and Meteorological Service of IMGW-PIB.

Selecting a method to classify atmospheric circulation usually results from the localisation and spatial extent of the study area as well as from the kind of analysed phenomena and their temporal scale (Ojrzyńska 2012). The authors employed Lityński method of classification of atmospheric circulation types (1969), as it is one of the more important and frequently used in meteorological and climatological studies in Poland (Nowosad 2004; Żmudzka 2007; Łupikasza 2010; Ustrnul et al. 2010, Kaszewski 2012). In addition, it is recognised as so-called objective classification for Middle Europe and often features in the works by Polish authors (PiankoKluczyńska 2007; Ustrnul \& Wypych 2011; Ustrnul et al. 2014). The original Lityński classification was based on the sea-level pressure field. Also the new, modified classification of circulation types is based on daily mean sea-level pressure obtained from reanalysis (Pianko-Kluczyńska 2007; Philipp et al. 2010; Bartoszek 2017).

For each record (date) from the years 2001-2010, the type of isobaric surface and direction of circulation were allocated, according to Lityński classification (1969), which was modified and standardised by Pianko-Kluczyńska (2007). The original calendar of Lityński circulation types (1968) was characterised by the non-homogeneity of material, which was caused by various sources of information about the pressure field (American, French and Polish synoptic charts, grid messages), and - resulting from these differences - varying accuracy of the obtained pressure fields. The modification by Pianko-Kluczyńska (2007), and later also by Philipp et al. (2010), consisted in preserving the homogeneity and at same time constantly updating of the catalogue. The types of atmospheric circulations were redefined, basing on the NCEP/NCAR Reanalysis data at 12.00 UTC (Kalnay et al. 1996). The class boundaries that are determined with the use of this classification illustrate the changes of the character of circulation in Euro-Atlantic sector well. It is particularly visible, when we shorten the period based on which the boundaries of classes are estimated. Then the division of distribution values of particular circulation indices is even closer to the equalprobability one (Kulesza 2017). Thus, it might be assumed that the results obtained for Legionowo are representative for the lowland area of Middle Europe. The zone and meridional indices were calculated with the use of 5-degree step of geographical latitude and longitude. The index defining the form of isobaric field was calculated based on the knot closest to Warsaw, i.e. $52.5^{\circ} \mathrm{N}$ and $20^{\circ} \mathrm{E}$, and therefore identical to the one for the nearby Legionowo. The original class boundaries that defined particular types were preserved. The classification includes 27 types of circulation. It takes into consideration 9 directions of air masses inflow over Poland, i.e.: $\mathrm{N}$ - northern, NE - north-eastern, E - eastern, SE - southeastern, S - southern, SW - south-western, 
W - western, NW - north-western, 0 - indefinite. In addition, this classification provides the information about three kinds of circulation, i.e.: the occurrence of cyclonic circulation " $c$ " (low pressure above middle area of Poland), neutral - "O", or anticyclonic - "a" (high pressure in the neighbourhood of Warsaw). Each type of circulation (indicating direction and kind) corresponds to a characteristic division of high and low baric pressure over Europe (Pawłowska et al. 2000).

The yearly average correspondence of the original Lityński circulation types (1968) with the new, modified ones is high, and for the years 1951-2003 and 1971-2015 equals respectively $78 \%$ and $79 \%$. Whereas the differences in the classification of around 21\% cases result from using different boundaries of the classes of circulation indices (PiankoKluczyńska 2007; Kulesza 2017). In turn, the yearly correspondence of particular components of the circulation type (meridional, zonal, transient components) reaches over $90 \%$ (Pianko-Kluczyńska 2007).

Since the radiosonde data were collected at 00 UTC, and atmospheric circulation data - at 12 UTC, the circulation from the same date, i.e. 12 hours later, was assumed for each radio sounding. The circulation data taken at 00 UTC are not available in publications at present. Consequently, a methodological problem arose - whether to use the data which are not burdened by radiation impact but are moved 12 hours in relation to circulation data, or to apply the data collected at 12 UTC, which would entail a big and difficult to assess radiation influence. Therefore, the authors used radiosonde data which were collected at 00 UTC and circulation type data taken at 12 UTC.

Primarily yearly average temperature values (January-December) and the locations of isobaric surfaces, such as 925,850 , 700 and $500 \mathrm{hPa}$ were subject of the analysis. In order to grasp seasonal changes, the authors investigated the average temperature values for winter (December-February) and summer (June-August) as well.
The number of particular directions and kinds of circulation indicates that anticyclonic weather dominated slightly over cyclonic during the year and in the summer. There were 1419 cases of anticyclonic weather (39.5\%), compared with 1242 cases of cyclonic (34.5\%). In the summer they occurred respectively in 380 cases (10.6\%) and in 298 cases (8.3\%). In turn, during the year and winter, meridional advections slightly dominated the zonal ones. This effect was not marked in the summer. An important feature throughout the year was the dominance of the inflow of air masses from the west quadrant (SW-WNW) over the east one (NE-E-SE). The frequency of the west and east quadrant air masses inflow was $37.6 \%$ and $28.4 \%$ accordingly. The predominance of west directions over the eastern ones was particularly pronounced in cyclonic types of circulation. Their frequency per year, winter and summer was accordingly 512 cases (41.2\%), 123 cases (39\%), 106 cases $(35.6 \%)$ and 301 cases $(24.2 \%)$, 66 cases (21\%) with 81 cases $(27.2 \%)$ (Tab. 1 ). The predominance of west directions during the year and winter in the analysed period is consistent with the results of research on atmospheric circulation, using the Lityński classification (1969), over Central and Eastern Europe in 1871-2010 (Bartoszek 2017).

\section{Results and Discussion}

Since the ground temperature affects the temperature of the lower layers of atmosphere and advective changes at the upper baric surfaces impact ground-level temperature, the authors investigated the power of these mutual interactions in the atmosphere above Legionowo. The analyses that were conducted in the 2001-2010 multiannual period proved a strong relationship between the ground-level temperature at the start of the radiosonde with the temperature of the investigated isobaric surfaces, i.e. 925, 850, 700 and 500 hPa. "R" correlation coefficients reach respectively the following values: $0.92 ; 0.88 ; 0.80$ and 0.79 . They are similar to the coefficients of analogous correlations 
Table 1. The amount of particular directions and kinds of circulation in the 2001-2010 multiannual period

\begin{tabular}{|c|c|c|c|c|c|c|c|c|c|c|}
\hline Kind & N & $\mathrm{NE}$ & E & SE & $S$ & sW & W & NW & 0 & Total \\
\hline \multicolumn{11}{|c|}{ Year } \\
\hline$a$ & 178 & 182 & 205 & 133 & 157 & 140 & 134 & 135 & 155 & 1419 \\
\hline c & 155 & 108 & 108 & 85 & 168 & 181 & 122 & 209 & 106 & 1242 \\
\hline 0 & 99 & 94 & 59 & 74 & 94 & 144 & 121 & 136 & 114 & 935 \\
\hline Total & 432 & 384 & 372 & 292 & 419 & 465 & 377 & 480 & 375 & 3596 \\
\hline \multicolumn{11}{|c|}{ Winter } \\
\hline a & 46 & 42 & 48 & 40 & 26 & 32 & 19 & 35 & 32 & 320 \\
\hline c & 35 & 21 & 22 & 23 & 60 & 49 & 26 & 48 & 31 & 315 \\
\hline 0 & 36 & 24 & 18 & 20 & 25 & 39 & 32 & 35 & 26 & 255 \\
\hline Total & 117 & 87 & 88 & 83 & 111 & 120 & 77 & 118 & 89 & 890 \\
\hline \multicolumn{11}{|c|}{ Summer } \\
\hline a & 43 & 50 & 61 & 30 & 41 & 35 & 46 & 35 & 39 & 380 \\
\hline c & 45 & 36 & 27 & 18 & 39 & 37 & 22 & 47 & 27 & 298 \\
\hline 0 & 19 & 21 & 14 & 15 & 26 & 27 & 35 & 32 & 32 & 221 \\
\hline Total & 107 & 107 & 102 & 63 & 106 & 99 & 103 & 114 & 98 & 899 \\
\hline
\end{tabular}

calculated in the years 1973-2002 for the atmosphere above Kraków (Bąkowski 2007).

The relationships under discussion are the strongest, but also affected by the biggest variability which is expressed by standard deviation, on the $925 \mathrm{hPa}$ surface; the higher is the surface, the weaker is the relationship between its temperature and ground-level temperature and the smaller is temperature variability. This results from the disappearing impact of the ground. Standard temperature deviations on the $925,850,700$ and $500 \mathrm{hPa}$ isobaric surfaces reach respectively: $8.3^{\circ} \mathrm{C}$; $7.5^{\circ} \mathrm{C} ; 6.8^{\circ} \mathrm{C}$ and $6.9^{\circ} \mathrm{C}$. The example of the correlation between the temperature at the start of the radiosonde and the temperature of the $925 \mathrm{hPa}$ surface is illustrated below (Fig. 1). Bakowski's research (2007) shows that during warm months the correlation relationship between air temperature in Stevenson Screen (2 $\mathrm{m}$ above ground level), and temperature on isobaric surfaces in the lower troposphere (obtained from reanalysis) over Kraków are the strongest (correlation coefficient $\geq 0.7$ ) and mainly determined by advection. The weakest correlation (linear correlation coefficient of 0.5 ) occurs in November, December and January. These are the months with the shortest days. The air temperature's changes at the ground level in winter are therefore caused by radiation rather than advection factors, which is supported by anticyclonal systems. The systems help to keep a constant balance and the associated inhibitory layers in the lower atmosphere, what causes thermal inversions (Bakowski 2007). In addition, the snow cover helps the air-temperature at ground level to stay low.

The above relationships, which resulted from the presented analysis, lead the authors to investigate how the type of atmosphere circulation - both in terms of its kind (the form of isobaric field) and the direction of air mass inflow - affects the temperature and location (height) of isobaric surfaces. Since isobaric and temperature fields relate to each other, the analysis of temperature field 
variability seems well-grounded. The results that were obtained for ground-level isobaric field can also refer to free troposphere (Asnani \& Mishra 1975). While Thorncroft and Hoskins (1990) in their work claim that temperature changes that occur at ground-level are especially conditioned by the changes of temperature field in lower- and mid-troposphere, in particular at the so-called advective level, which corresponds to the $850 \mathrm{hPa}$ isobaric surface. These claims find their confirmation in the line of air temperature at groundlevel which was based on radiosonde measurements and in the location of individual isobaric surfaces (Fig. 2).
The analysis of the results obtained from radio soundings at 00 UTC in the 20012010 multiannual period justifies the claim that throughout the year and in summer with anticyclonic circulation kind the average temperature at ground-level, as well as that on the isobaric surfaces in the lower troposphere (up to $850 \mathrm{hPa}$ ), is lower than that which occurs during the cyclonic one. In winter an analogous situation takes place, except that it also refers to the $700 \mathrm{hPa}$ surface (Tab. 2). This most probable results from the fact that in a relatively dry air mass during winter anticyclones temperature decreases faster with height (the drop being similar

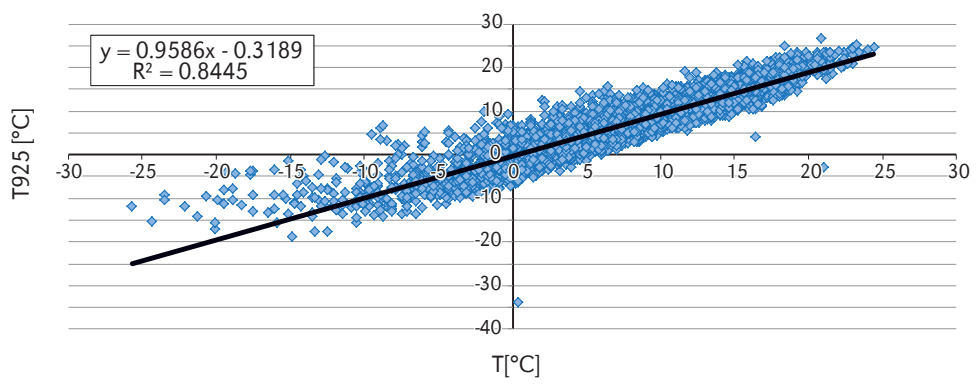

Figure 1. The correlation between ground-level temperature and the temperature of the $925 \mathrm{hPa}$ isobaric surface in the 2001-2010 multiannual period

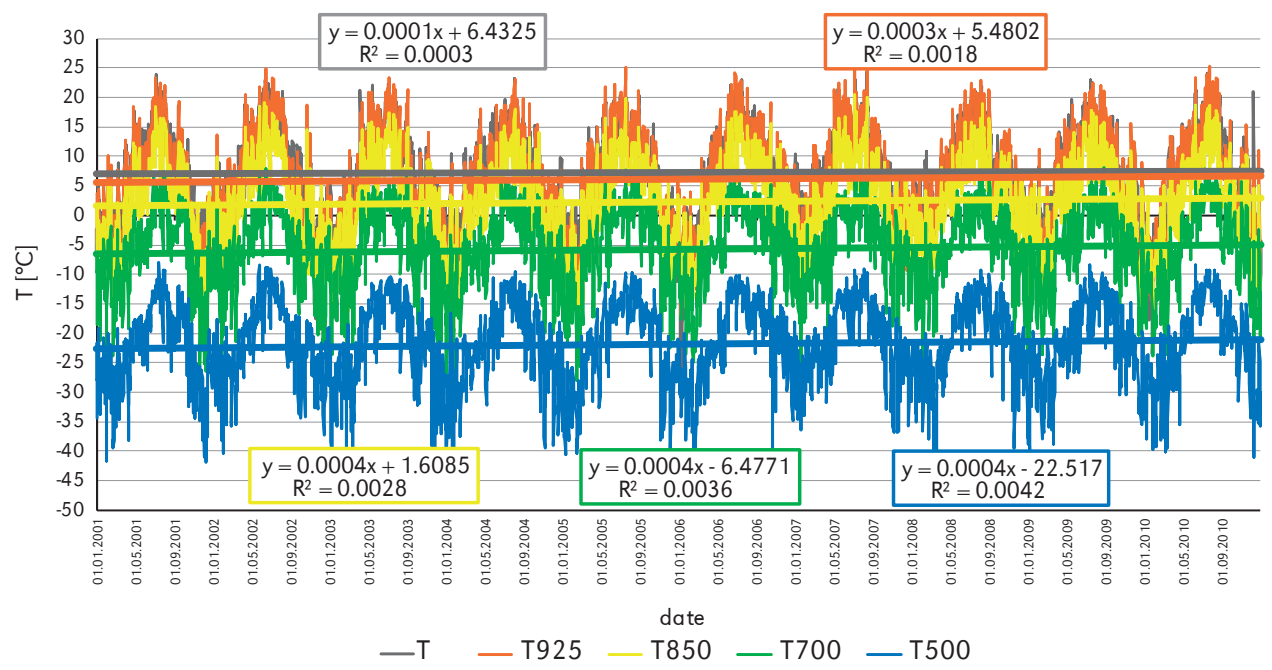

Figure 2. The course of air temperature at ground-level and on isobaric surfaces with trend lines and regression equations in the 2001-2010 multiannual period 
to dry adiabatic lapse rate) than during more humid winter cyclonic systems.

There is a rule that in the case of anticyclonic circulation the analysed isobaric surfaces are located higher the in the case of cyclonic ones. The yearly mean differences between the location of 925,850,700 and $500 \mathrm{hPa}$ isobaric surfaces between anticyclonic and cyclonic circulation is about 127 , 125, 125 and $131 \mathrm{~m}$., respectively. Similarly, the average air temperature changes $-0.3^{\circ} \mathrm{C}$ at the $850 \mathrm{hPa}$ surface to $-1.1^{\circ} \mathrm{C}$ at the ground level. In winter, when massive anticyclones develop over Europe, the mean differences are greater that in summer (Tab. 2), they depend not only on the circulation nature but also on the dynamics of individual baric systems - powerful systems of high pressure, characteristic for winter, relatively not very dynamic, cause multi-day episodes of high pressure at sea level and thus a higher position of the appropriate isobaric surfaces, what gives the above effect after averaging.
Regardless of the kind of circulation, the average location of isobaric surfaces above Legionowo in the 2001-2010 multiannual period increased slightly, compared to the analogous heights in the years 1961-1985, which were calculated by Pyka (1990). For example, the average height of the $850 \mathrm{hPa}, 700 \mathrm{hPa}$ and $500 \mathrm{hPa}$ isobaric surfaces increased by $3 \mathrm{~m}, 7 \mathrm{~m}$ and $11 \mathrm{~m}$ respectively. These growth values are small to such an extent that it cannot be determined whether they are caused by the climate change or related to the change of sounding equipment.

The details of the above are presented in the lines of locations and temperatures of isobaric surfaces throughout the whole year, during particular kinds of circulation (Figs. 3-4). In each month of the year, during anticyclonic circulation individual isobaric surfaces are located higher that during cyclonic circulation (Fig. 3). The highest locations above sea level occur in the warm season of the year, since May till October, the maximum being

Table 2. Average temperature $\mathrm{T}\left[{ }^{\circ} \mathrm{C}\right]$ and average location $\mathrm{H}$ [m a.s.I.] of isobaric surfaces during circulation kinds in the 2001-2010 multiannual period

\begin{tabular}{|c|c|c|c|c|c|c|c|c|c|}
\hline Kind & H925 & H850 & $\mathrm{H} 700$ & $\mathrm{H} 500$ & T & T925 & T850 & T700 & T500 \\
\hline \multicolumn{10}{|c|}{ Year } \\
\hline a & 831 & 1,519 & 3,066 & 5,630 & 6.2 & 5.8 & 2.2 & -5.5 & -21.3 \\
\hline 0 & 770 & 1,458 & 3,004 & 5,562 & 6.5 & 5.9 & 2.1 & -5.9 & -21.9 \\
\hline c & 705 & 1,395 & 2,941 & 5,498 & 7.3 & 6.6 & 2.5 & -6.0 & -22.1 \\
\hline Overall & 772 & 1,460 & 3,006 & 5,567 & 6.7 & 6.1 & 2.3 & -5.8 & -21.7 \\
\hline \multicolumn{10}{|c|}{ Winter } \\
\hline a & 842 & 1,508 & 3,014 & 5,513 & -4.1 & -4.1 & -5.4 & -12.0 & -27.8 \\
\hline 0 & 756 & 1,425 & 2,934 & 5,437 & -1.5 & -2.4 & -4.7 & -11.6 & -27.5 \\
\hline c & 667 & 1,339 & 2,849 & 5,349 & -0.2 & -1.0 & -4.1 & -11.7 & -28.0 \\
\hline Overall & 755 & 1,424 & 2,932 & 5,433 & -2.0 & -2.5 & -4.7 & -11.8 & -27.8 \\
\hline \multicolumn{10}{|c|}{ Summer } \\
\hline a & 824 & 1,534 & 3,120 & 5,748 & 15.4 & 14.8 & 9.7 & 0.8 & -14.7 \\
\hline 0 & 785 & 1,496 & 3,084 & 5,712 & 15.5 & 15.2 & 10.2 & 0.8 & -14.8 \\
\hline c & 741 & 1,452 & 3,038 & 5,662 & 15.4 & 14.9 & 9.9 & 0.2 & -15.1 \\
\hline Overall & 783 & 1,494 & 3,081 & 5,707 & 15.4 & 15.0 & 9.9 & 0.6 & -14.9 \\
\hline
\end{tabular}



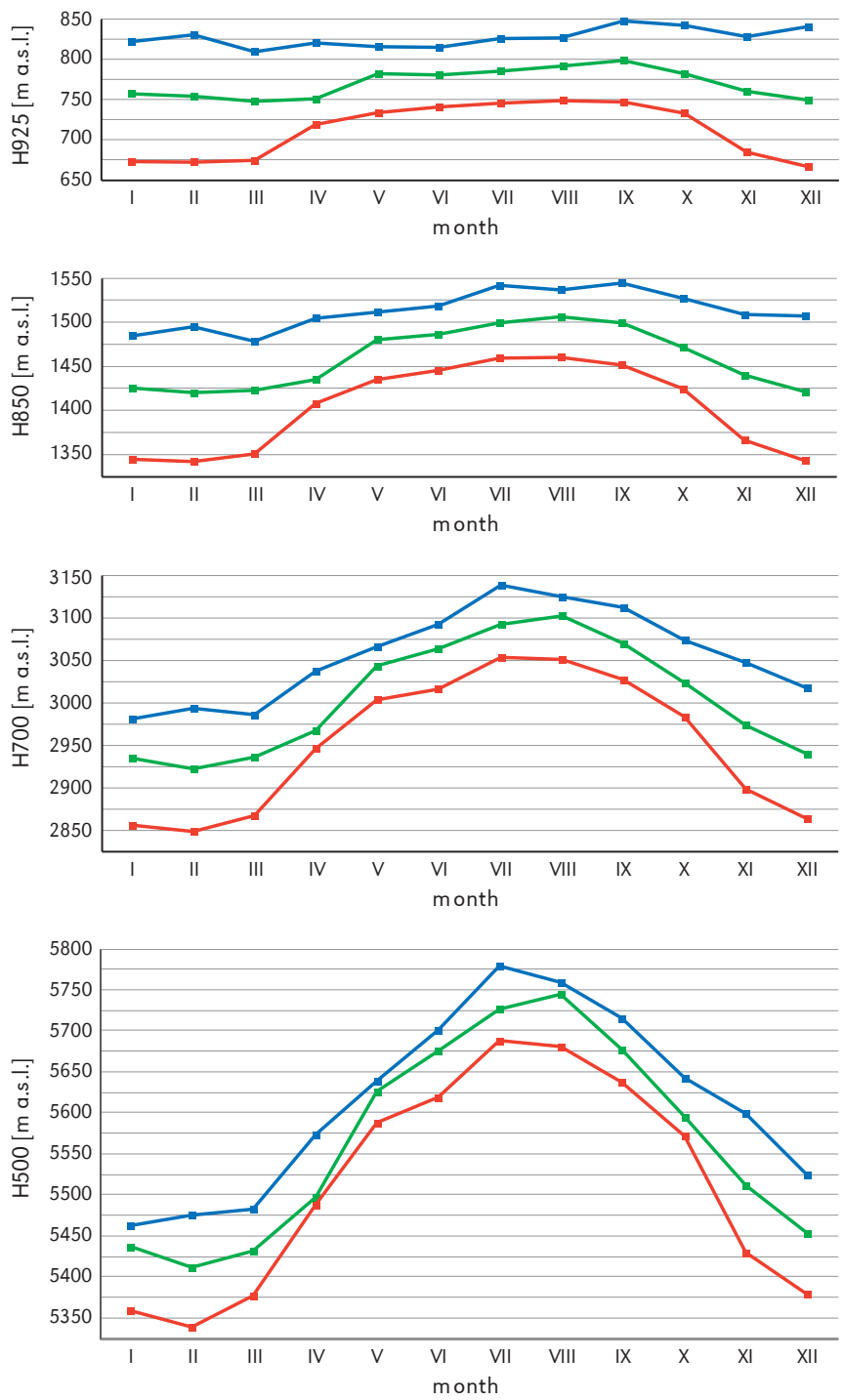

$\rightarrow \mathrm{a}=0 \quad-\mathrm{c}$

Figure 3. The yearly lines of isobaric surface locations during particular kinds of circulation in the 20012010 multiannual period

reached in August or July. The lowest ones occur since November till March, with the minimum located in the lower troposphere (925 and $850 \mathrm{hPa}$ ) being reached in March, and at higher surfaces (700 and $500 \mathrm{hPa}$ ) - in January. It is worth noting that the biggest differences among the locations of isobaric surfaces during anticyclonic and cyclonic circulation kinds take place in winter months (December-January), when the maximum one is reached in December. Then they fall in the range between ca. $146 \mathrm{~m}$ for the $500 \mathrm{hPa}$ surface to $174 \mathrm{~m}$ for the $925 \mathrm{hPa}$ surface (Fig. 3). On the contrary, the slightest differences between the anticyclonic and cyclonic kind of circulation occur from May to September. 

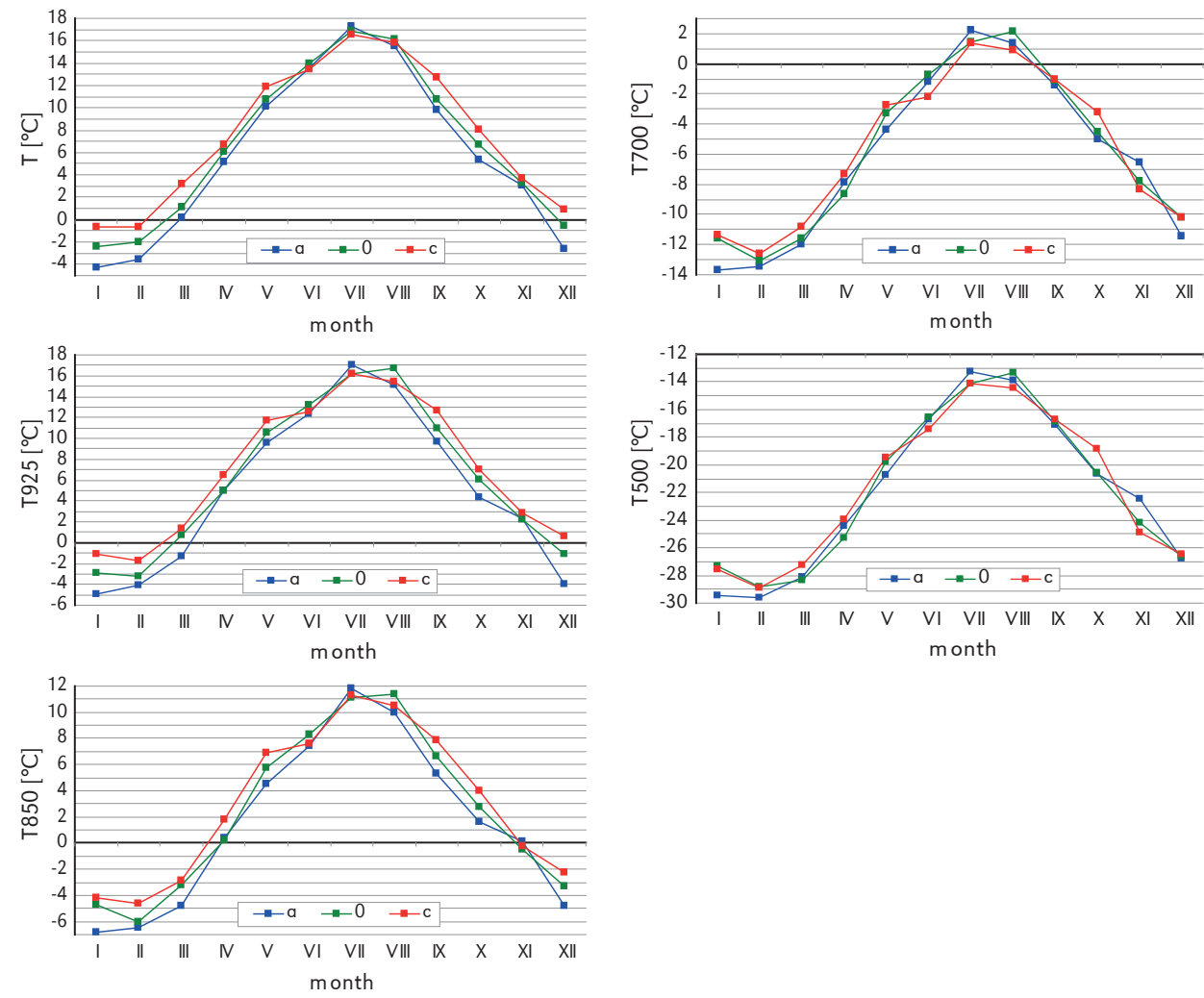

Figure 4. The yearly lines of air temperatures at the start of the sonde $(\mathrm{T})$ and the temperatures of the T925, T850, T700 and T500 hPa isobaric surfaces during particular kinds of circulation in the 20012010 multiannual period

The minimum difference is 73-76 $\mathrm{m}$ for the 925, 850 and 700 Pa surfaces and occurs in June. Only for the $500 \mathrm{hPa}$ surface it occurs in May and amounts $51 \mathrm{~m}$ (Fig. 3). The characteristics of June, such as: long day, intensive sunlight and turbulent heat exchange, do not form propitious circumstances for night temperature inversions. It can be stated that in the warm season the temperature changes at the ground-level and the locations of isobaric surfaces are to a great extent conditioned by advective changes. While the reasons for the biggest differences in winter season should be sought in, among other factors, the intensified impact of anticyclonic systems, which facilitate temperature inversions and the cooling of the lower layers of atmosphere by the snow cover during its retention.
Lityński (1969) and Bąkowski (2007) share this opinion.

The situation with the yearly lines of average air temperature at ground-level and on individual isobaric surfaces looks similar. Regardless of the circulation kind, they relate to the classical yearly the course of average temperature at moderate latitudes. The highest average values occur in summer, with the maximum ones falling in July, while the lowest average values appear in winter, with the minimum one falling in January or February (Fig. 4). For the anticyclonic circulations the minimum temperatures occur in January (except the $500 \mathrm{hPa}$ surface, where it happens in February and the temperature is $-29.6^{\circ} \mathrm{C}$ ) and they reach: $-4.3^{\circ} \mathrm{C}(\mathrm{T}$ at the start of the sonde), $-5.0(925 \mathrm{hPa}),-6.8^{\circ} \mathrm{C}(850 \mathrm{hPa})$, 
$-13.7^{\circ} \mathrm{C}(700 \mathrm{hPa})$ and $-29.5^{\circ} \mathrm{C}(500 \mathrm{hPa})$. While for the cyclonic and non-gradient kinds of atmospheric circulation, the minimum temperature occurs in February, except for the lowest level - the starting point of the radiosonde, for which the minimum appears in January and reaches the value of $-0.7^{\circ} \mathrm{C}$ in the case of the cyclonic types and $-2.4^{\circ} \mathrm{C}$ in the case of non-gradient ones. Regardless of the circulation kind, the increase in temperature from minimum to maximum on all isobaric surfaces is slower than its decrease from maximum to minimum. For a longer time of the year (4-5 months) the temperature of the surfaces under study above Legionowo stays around the minimum value, and high temperature values are observed for 2-3 months (Fig. 4). Analogous conclusions result from the radio sounding studies of atmosphere for all stations in the zone of moderate altitudes (Pyka 1990).

In summer months (June-August), during anticyclonic types of circulation, the temperature of the 700 and $500 \mathrm{hPa}$ surfaces is marked by higher average values than during cyclonic ones. In the case of July, this situation is visible on all the analysed surfaces (Fig. 4). This means that anticyclonic kinds of circulation, regardless their direction, cause the advections of warm air masses.

Once the location and temperature of the analysed isobaric surfaces during different types of circulation have been investigated, the next step is to study them in the context of both circulation directions and the direction combined with a given kind, which together form circulation type (NWa, NWc, NW0, etc.). In the light of the directions of air masses inflow, according to the calendar accepted for the purpose of this study, it can be observed that they significantly affect the parameters of isobaric surfaces that are being characterised. Namely, throughout the whole year and in summer and winter, with the directions from the northern quadrant (NW-N-NE), the individual isobaric surfaces are marked by lowest temperatures, and at the same time they are are located at the lowest level. Thus, these are typically the directions of cold advection. For example, with the norther direction, the average year temperatures and locations of the 925, 850, 700, $500 \mathrm{hPa}$ isobaric surfaces equal respectively: $4.0^{\circ} \mathrm{C}$ and $754 \mathrm{~m}, 0.1^{\circ} \mathrm{C}$ and $1437 \mathrm{~m}$, $-8.1^{\circ} \mathrm{C}$ and $2970 \mathrm{~m},-24.0^{\circ} \mathrm{C}$ and $5507 \mathrm{~m}$. In turn, throughout the year and in winter, for the SW and W directions, the highest temperatures of particular surfaces are noted, these surfaces being then located relatively high (Tab. 3, Figs. 5-8). The result confirms the earlier observations by Degirmendžić and Kożuchowski (2017), that in winter months (XII-II, i.e., Dec-Feb) the mean air temperature in Poland as well as the height of isobaric surfaces over the south of $\left(40-45^{\circ} \mathrm{N}\right.$ area) have a strong, positive correlation. In contrast, in the North Atlantic $\left(60-70^{\circ} \mathrm{N}\right.$ area), the correlation is negative. This isocorella system illustrates the influence of west and southwest circulation on the increase of air temperature in winter in Poland (Degirmendžić \& Kożuchowski 2017). For example, in the case of south-western direction, the average yearly temperatures and locations of the analysed surfaces, from the lowest to the highest, equal respectively: $8.0^{\circ} \mathrm{C}$ and $782 \mathrm{~m}$, $4.2^{\circ} \mathrm{C}$ and $1476 \mathrm{~m},-4.0^{\circ} \mathrm{C}$ and $3033 \mathrm{~m}$ and $-20.0^{\circ} \mathrm{C}$ and $5610 \mathrm{~m}$ (Tab. 3). The advection from these directions is a warm one. It was Seweryńska (1978) that pointed out that the intensification of zonal circulation at the $500 \mathrm{hPa}$ surface affected the shaping of positive anomalies of air temperature in Poland (except in summer, when they bring temperature reduction). Similarly, Wibig (2001) considers the changes of zonal circulation (positive phase of Northern-Atlantic Oscillation) to be the main cause of the changeability of temperatures in winter, while in the rest of the seasons the meridional types of circulations at the $500 \mathrm{hPa}$ surface affect temperature.

The temperatures on isobaric surfaces vary significantly in the seasons that are extreme with regard to temperature. Namely, while in winter the circulations from SW, W and NW directions constitute warm advections, in summer the following directions, starting from $\mathrm{W}$, through NW to $\mathrm{N}$ are 
Table 3. Average temperature $\mathrm{T}\left[{ }^{\circ} \mathrm{C}\right]$ and average location $\mathrm{H}$ [m a.s.I.] of isobaric surfaces with regard to the direction of atmospheric circulation in the 2001-2010 multiannual period

\begin{tabular}{|c|c|c|c|c|c|c|c|c|c|}
\hline Direction & H925 & H850 & $\mathrm{H} 700$ & H500 & T & T925 & T850 & T700 & T500 \\
\hline \multicolumn{10}{|c|}{ Year } \\
\hline$N$ & 754 & 1,437 & 2,970 & 5,507 & 5.8 & 4.0 & 0.1 & -8.1 & -24.0 \\
\hline $\mathrm{NE}$ & 773 & 1,458 & 2,995 & 5,542 & 6.4 & 4.8 & 0.8 & -7.2 & -23.1 \\
\hline E & 789 & 1,478 & 3,027 & 5,593 & 6.2 & 5.8 & 2.4 & -5.2 & -21.2 \\
\hline SE & 785 & 1,475 & 3,024 & 5,589 & 5.7 & 6.0 & 2.7 & -5.2 & -21.5 \\
\hline S & 773 & 1,464 & 3,017 & 5,586 & 6.1 & 7.1 & 3.4 & -4.8 & -21.0 \\
\hline SW & 782 & 1,476 & 3,033 & 5,610 & 7.4 & 8.0 & 4.2 & -4.0 & -20.0 \\
\hline W & 770 & 1,462 & 3,014 & 5,585 & 8.2 & 7.4 & 3.4 & -4.8 & -20.6 \\
\hline NW & 753 & 1,441 & 2,982 & 5,536 & 7.6 & 5.7 & 1.6 & -6.5 & -22.3 \\
\hline 0 & 773 & 1,462 & 3,006 & 5,564 & 6.2 & 5.8 & 2.0 & -6.0 & -22.0 \\
\hline \multicolumn{10}{|c|}{ Winter } \\
\hline N & 732 & 1,398 & 2,896 & 5,372 & -2.2 & -3.4 & -6.1 & -14.0 & -30.2 \\
\hline NE & 764 & 1,424 & 2,913 & 5,385 & -2.6 & -6.0 & -8.3 & -14.9 & -30.4 \\
\hline$E$ & 783 & 1,445 & 2,945 & 5,438 & -9.6 & -5.7 & -7.1 & -12.8 & -28.4 \\
\hline SE & 766 & 1,434 & 2,945 & 5,450 & -1.6 & -3.4 & -4.8 & -11.1 & -27.7 \\
\hline$S$ & 737 & 1,407 & 2,919 & 5,427 & -4.9 & -2.2 & -4.2 & -11.1 & -27.2 \\
\hline SW & 770 & 1,448 & 2,974 & 5,501 & 0.2 & 1.3 & -1.4 & -9.0 & -25.1 \\
\hline W & 761 & 1,435 & 2,958 & 5,483 & 1.4 & -0.2 & -2.3 & -9.5 & -25.2 \\
\hline NW & 749 & 1,421 & 2,936 & 5,444 & -0.7 & -0.7 & -3.3 & -11.0 & -27.1 \\
\hline 0 & 748 & 1,413 & 2,913 & 5,397 & -4.5 & -4.1 & -6.2 & -13.3 & -29.3 \\
\hline \multicolumn{10}{|c|}{ Summer } \\
\hline N & 774 & 1,480 & 3,057 & 5,672 & 15.8 & 13.2 & 8.3 & -0.7 & -16.2 \\
\hline NE & 787 & 1,495 & 3,078 & 5,701 & 14.7 & 14.2 & 9.3 & 0.1 & -15.5 \\
\hline E & 805 & 1,519 & 3,115 & 5,753 & 15.6 & 16.2 & 11.5 & 2.0 & -13.6 \\
\hline SE & 804 & 1,519 & 3,114 & 5,752 & 15.4 & 16.7 & 11.6 & 1.8 & -13.8 \\
\hline$S$ & 793 & 1,506 & 3,100 & 5,738 & 16.0 & 16.3 & 11.1 & 1.7 & -13.8 \\
\hline SW & 792 & 1,504 & 3,094 & 5,727 & 16.8 & 16.0 & 10.5 & 1.2 & -14.3 \\
\hline W & 784 & 1,493 & 3,075 & 5,697 & 14.1 & 14.3 & 9.2 & 0.0 & -15.4 \\
\hline NW & 766 & 1,472 & 3,048 & 5,661 & 13.7 & 13.1 & 8.1 & -1.0 & -16.0 \\
\hline 0 & 789 & 1,501 & 3,090 & 5,720 & 16.5 & 15.5 & 10.4 & 1.0 & -14.5 \\
\hline
\end{tabular}

evidently cold advections. This results from the physical properties that a given air mass acquired above the source area. In winter relatively warm and humid air flows from the Northern Atlantic in the western sector; in summer this advection is relatively cold and humid. Consequently, there occur the presented implications for the temperature and locations of isobaric surfaces. Interesting looks the situation with the advection of air 


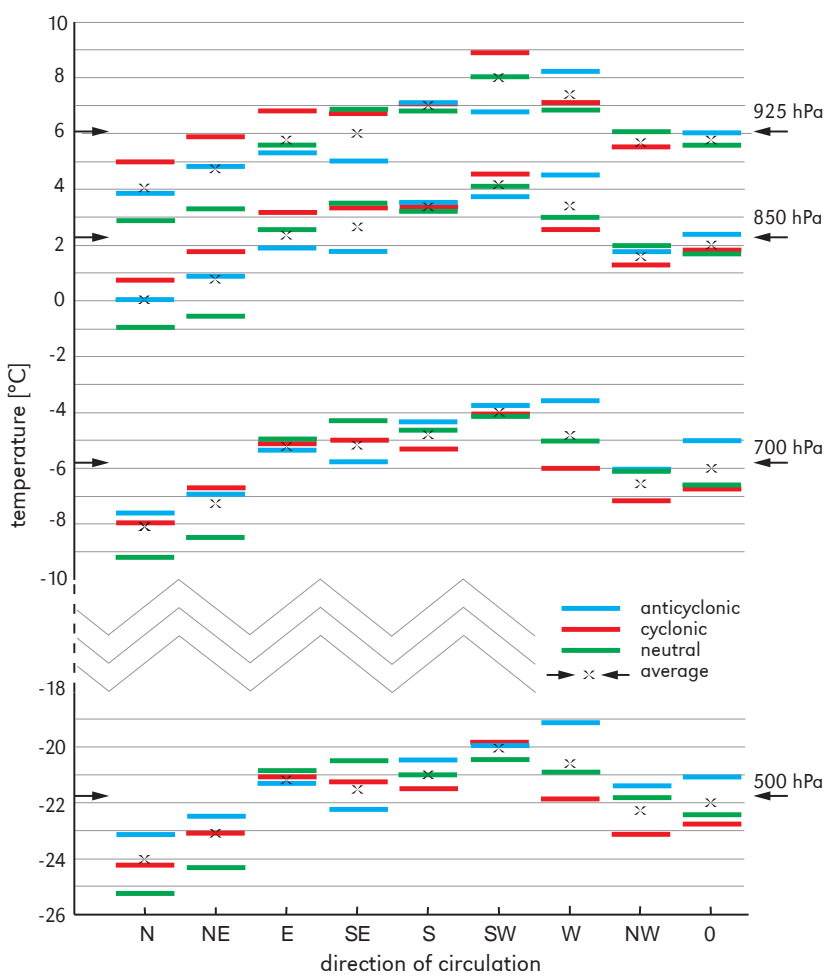

Figure 5. Air temperature on isobaric surfaces in relation to the type of atmospheric circulation in the 2001-2010 multiannual period

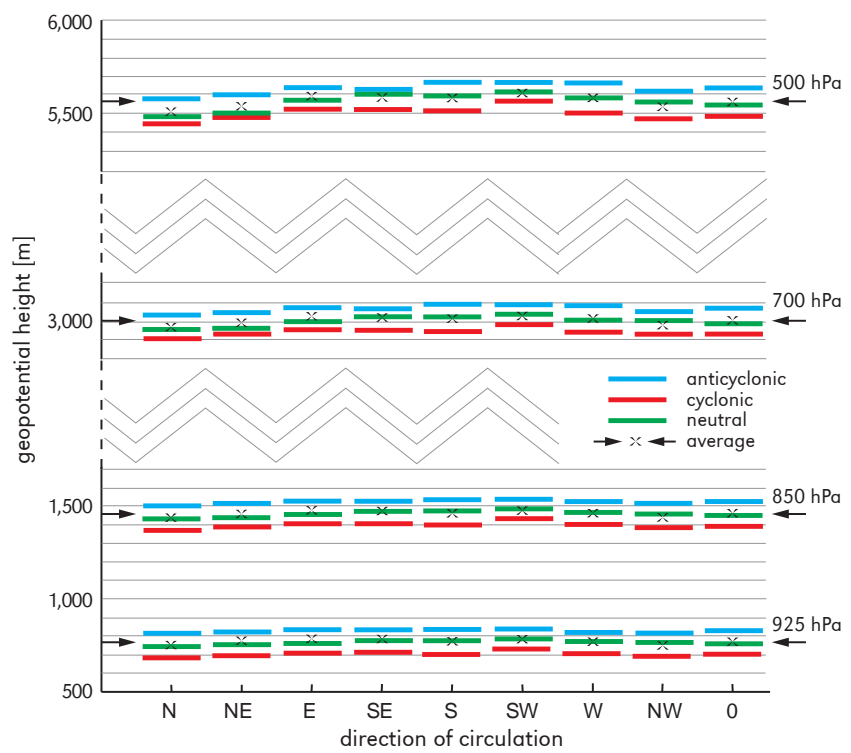

Figure 6. The height of isobaric surfaces in relation to the type of atmospheric circulation in the 20012010 multiannual period 


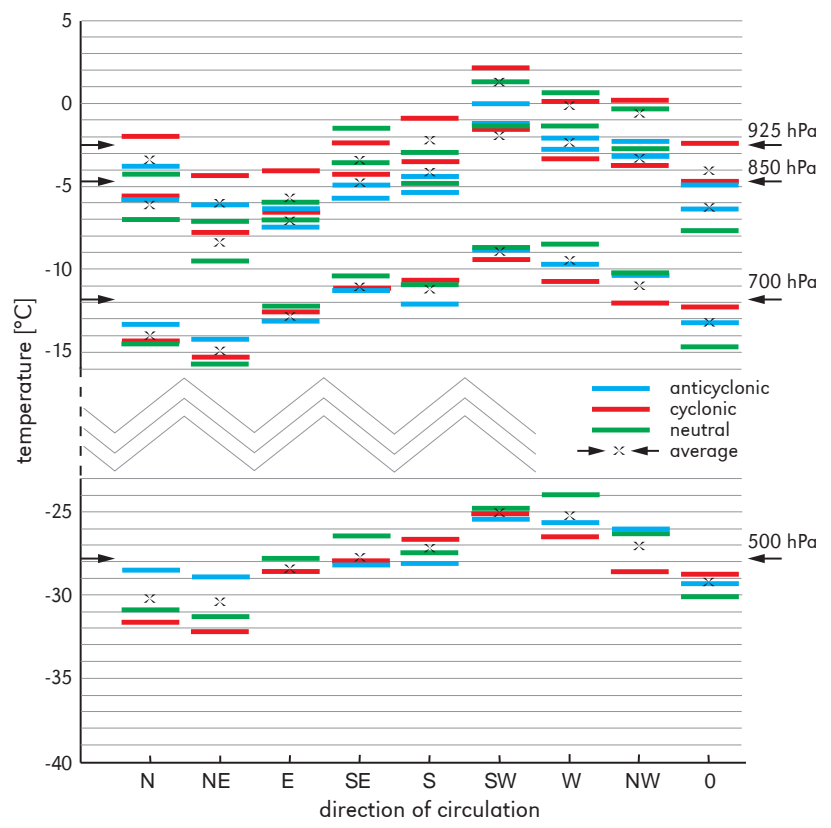

Figure 7. Winter air temperature on isobaric surfaces in relation to the type of atmospheric circulation in the 2001-2010 multiannual period

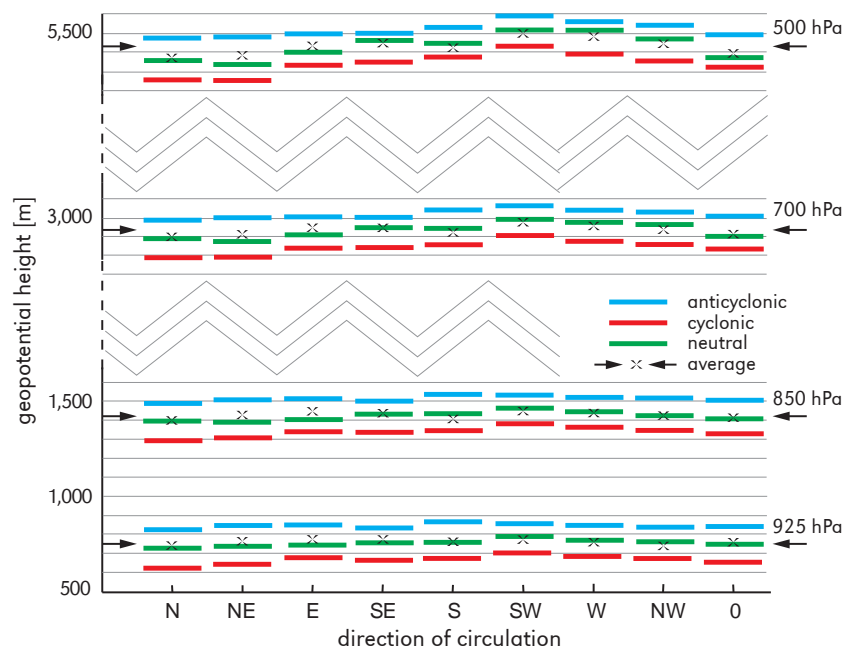

Figure 8. The height of isobaric surfaces in relation to the type of atmospheric circulation in winter, in the 2001-2010 multiannual period

masses from NE and NW. In winter NE direction brings the coldest air on all isobaric surfaces. Whereas NW direction brings the same situation in summer. In turn, the advection of warm air masses in summer, which is distinct on the analysed surfaces, is mainly caused by four directions: E, SE, S and SW, SW direction playing a much weaker warming role than it does in winter or throughout the whole year (Tab. 3; Figs. 7, 9). 
In summer season high temperature in Poland correlates with the height of the geopotential over Mid-Eastern Europe. Then the mutual interactions between temperature and the $500 \mathrm{hPa}$ geopotential appear more distinctly-in warm air masses $500 \mathrm{hPa}$ surface raises. It can be stated that in summer advection becomes less significant, while the role of insolation, which is related to anticyclonic type of weather, increases. (Degirmendžić \& Kożuchowski 2017). A similar conclusion can be drawn from the work of Bartoszek (2017), who showed an increased frequency of the anticyclonic type of circulation over Central and East Europe in summer in 1871-2010.

When analysing different circulation situations, it might be observed that throughout the year as well as in winter and summer the lowest isobaric surfaces occur during circulations from the northern quadrant. Also, they are accompanied by the lowest air temperatures at the analysed surfaces (Figs. 5-10). Thus, these circulations bring cold air advections. Warm air inflows during the circulations from the following directions: starting from $E$ through $S$ to $W$, SW and $W$ being particularly privileged in this respect. Similarly, Bąkowski (2007) emphasised that the changes of advections that caused the increase of temperature in southern Poland occurred during circulation types from SW and S, both at the high and low pressure. While Degirmendžić (2003), investigating the influence of advection at the $850 \mathrm{hPa}$ surface on temperature, defined the directions bringing warm and cold waves in Łódź. The advections from S-W are responsible for warm waves, while cold waves are caused by the advections from NE and $E$ in winter and in summer from $W$ and NW.

Annually, the kind of E circulation is not insignificant - Ec circulation is on average warmer than Ea by $1.5^{\circ} \mathrm{C}$ on $925 \mathrm{hPa}$ isobaric surface, by $1.3^{\circ} \mathrm{C}$ on $850 \mathrm{hPa}$, by $0.3^{\circ} \mathrm{C}$ on $700 \mathrm{hPa}$ and by $0.2^{\circ} \mathrm{C}$ on $500 \mathrm{hPa}$. While in the case of western circulation this impact is the opposite - Wa is on average warmer than $\mathrm{Wc}_{\mathrm{c}}$ by $1.1^{\circ} \mathrm{C}$ on the $925 \mathrm{hPa}$ isobaric surface, by $1.9^{\circ} \mathrm{C}$ on $850 \mathrm{hPa}$, by $2.4^{\circ} \mathrm{C}$ on $700 \mathrm{hPa}$ and by $2.7^{\circ} \mathrm{C}$ on $500 \mathrm{hPa}$ (Fig. 5).

The interpretation of this situation is obvious, when we take into consideration what

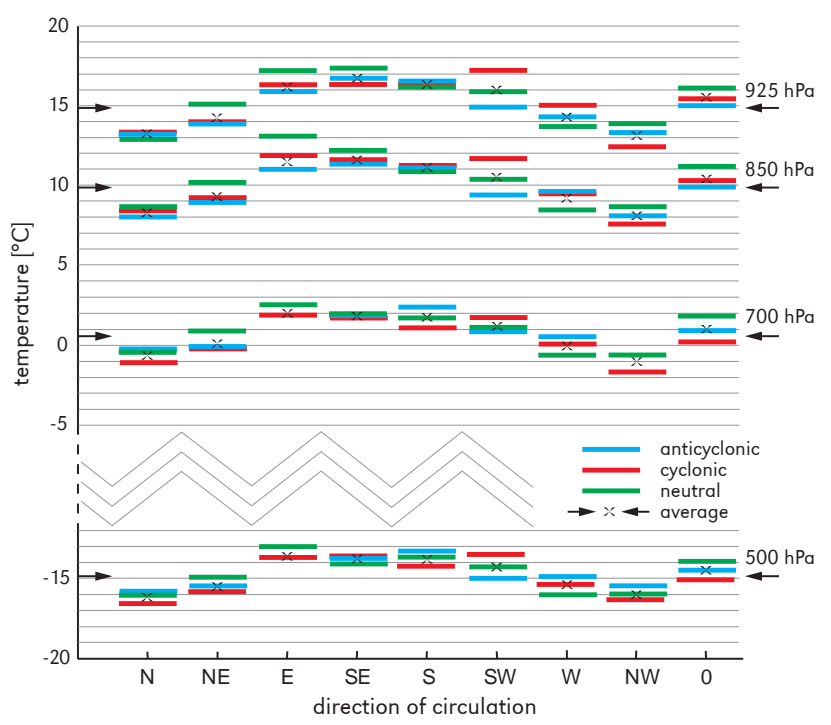

Figure 9. Summer air temperature on isobaric surfaces in relation to the type of atmospheric circulation in the 2001-2010 multiannual period 


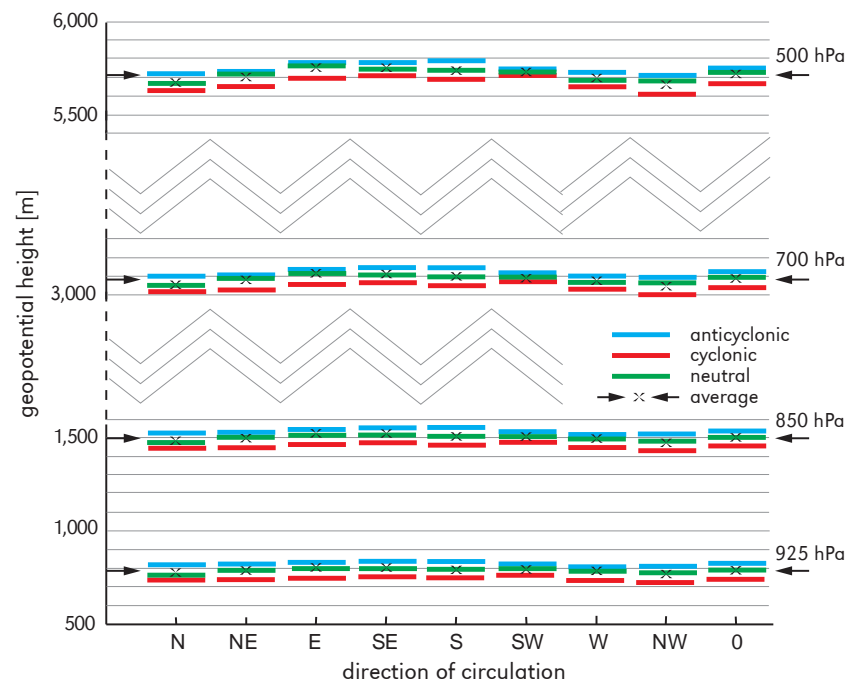

Figure 10. The height of isobaric surfaces in relation to the type of atmospheric circulation in summer, in the 2001-2010 multiannual period

the pressure field that determines the advection in the area further from Warsaw looks like. The example of the situation with Ec circulation is presented in Figure 12. In the illustrated case of Ec circulation, air inflows to the region of Warsaw from the east, but its source area is Black Sea region. The rule can be assumed, which says that in the case of Ec and Wa circulations, the curve of air inflows from the south-east/south-west, and it assumes respectively eastern/western direction relatively close to Warsaw. In the case of Ea and Wc circulations the situation is the opposite, which means that the curve of air mass inflows from the north-east/ north-west, assuming, as before, respectively eastern/western direction close to Warsaw. Whereas it has not been explained yet why in the case of the advection from the eastern direction throughout the year temperature differences between the kinds of circulations at the higher surfaces (700 hPa and $500 \mathrm{hPa}$ ) are an order of magnitude smaller than in the case of the advection from the west (Fig. 5). However, it is known that in the NEa situation the anticyclonic centre is located in the southern Scandinavia. In the cold season it causes the arctic air flow to Central Europe. To the south of anticyclone there is a widespread cyclonic area, stretching between the Azores and the Mediterranean. Sometimes, there are separate upper cyclones in this area. In such a case, there is a different airflow direction at groundlevel and at higher surfaces of atmosphere. Probably for this reason, there are noticeably smaller temperature differences at the higher surfaces during east advection rather than the west ones, for distinct types of circulation.

For $\mathrm{E}$ circulation, the situation in winter is similar, but with a smaller amplitude than throughout the whole year (Fig. 7). While for summer, Ec is warmer from Ea only on the lower isobaric surfaces (Fig. 9). Some diversity in this respect can result from the disproportionate occurrence frequencies of a given kind of circulation on the eastern direction. Namely, anticyclonic kind appeared, both in winter and in summer, twice more often than the cyclonic one (Tab. 1).

In turn, Sc circulation throughout the year and in summer is usually colder than Sa circulation, and in winter the situation is the opposite. Na circulation, both throughout the year and in individual seasons, is colder than 
Nc circulation at the 925 and $850 \mathrm{hPa}$ surfaces, but it is warmer at the 700 and $500 \mathrm{hPa}$ surfaces (Figs. 5, 7, 9).

To summarise, northern circulations affect atmosphere temperature to a greater extent than southern ones. It is an obvious rule that all isobaric surfaces, regardless of circulation direction, are located lower during the cyclonic kind of circulation than during the anticyclonic one, because the first is connected with low pressure system and the latter - the opposite (Fig. 11). This relationship occurs both throughout the whole year as well as in winter and summer (Figs. 6, 8, 10).

\section{Summary and Conclusions}

The analysis of the temperature and location of the selected isobaric surfaces in the troposphere above Legionowo, which was conducted on the basis of radiosonde measurements at 00 UTC in the years 2001-2010, enables us to put forward the following claims:

1. There exists a distinct relationship between the temperature of the analysed isobaric surfaces and the temperature at groundlevel, the coefficients of correlation are ca. 0.9-0.8.

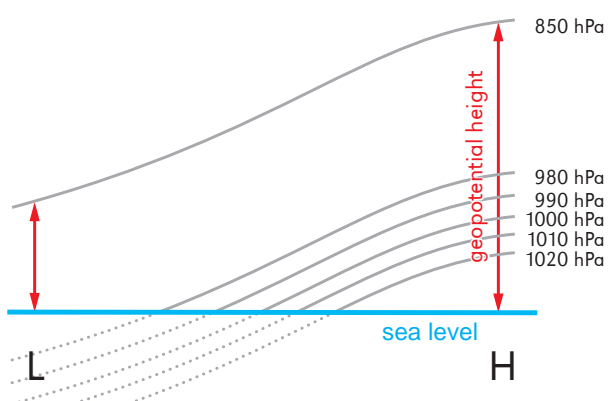

Figure 11. The diagram of isobaric surfaces locations in relation to pressure system ( $\mathrm{L}-$ low pressure, $\mathrm{H}$ - high pressure)

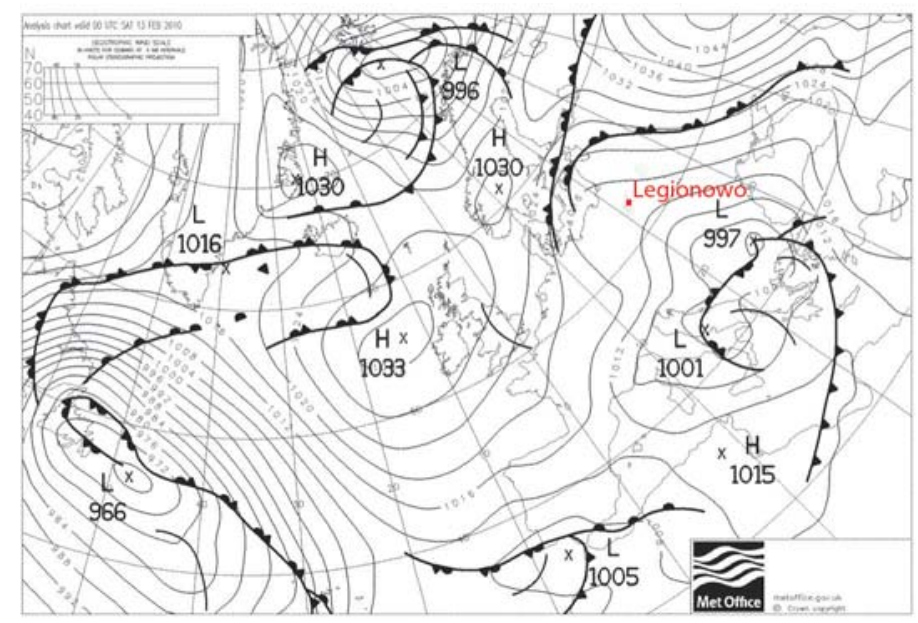

Figure 12. Synoptic chart over Europe from 13 Feb. 2010 at 00 UTC

Source: http://www.wetterzentrale.de [access 7 Feb 2017]. 
2. The analysis of only the kind of circulation (cyclonic, neutral, anticyclonic), excluding its direction, indicates the following:

a. During anticyclonic kind of circulation, the average yearly temperature as well as the average temperature in the individual months at the ground-level and on isobaric surfaces are lower than during cyclonic one. Then isobaric surfaces are located higher above sea level.

b. The isobaric surfaces from $925 \mathrm{hPa}$ to $500 \mathrm{hPa}$ are located at the highest level above sea in the warm season of the year, the maximum occurring in August or July (except $925 \mathrm{hPa}$ for anticyclonic and neutral kinds - the maximum appears in September).

c. The isobaric surfaces located at the lowest levels occur between November and March. The minimum for the anticyclonic kinds of circulation in lower troposphere (925 and $850 \mathrm{hPa}$ ) appears in March, and at the higher surfaces (700 and $500 \mathrm{hPa}$ ) - in January. The minimum for cyclonic and neutral kinds at higher surfaces occurs in February.

d. The biggest differences between the locations of isobaric surfaces during anticyclonic and those during cyclonic kind of circulation occur in winter, the maximum appearing in December. Then they range from ca. $146 \mathrm{~m}$ for the $500 \mathrm{hPa}$ surfaces to $174 \mathrm{~m}$ for the $925 \mathrm{hPa}$ surfaces. On the contrary, the individual isobaric surfaces are located the closest to each other since May till September. The smallest differences, ca. $75 \mathrm{~m}$ for the surfaces from 925 to $700 \mathrm{hPa}$ appear in June. The exception is the $500 \mathrm{hPa}$ surface, for which the smallest difference occurs in May and is $51 \mathrm{~m}$.

e. The highest average values of isobaric surfaces temperatures occur in summer, the maximum being in July. In turn, the lowest average values are noted in winter, the minimum being recorded in January or February. f. On all isobaric surfaces the increase of temperature from minimum to maximum is slower than its decrease from maximum to minimum. During a longer period of the year (4-5 months) the temperatures of isobaric surfaces under study over Legionowo stay close to the minimum value, and high temperatures are observed for 2-3 months.

3. The analysis of atmospheric circulation direction, regardless of the kind of circulation, leads to the conclusion that throughout the year, in winter and in summer with the direction from the northern quadrant (NW-N-NE) isobaric surfaces are marked by the lowest temperatures and are located at the same time at the lowest levels. Therefore, they are the typical directions of cold advection. In turn, throughout the year and in winter SW and W directions correlate with the highest temperature values of individual surfaces, and then these surfaces are located at the relatively highest levels. The advection of air masses from these directions is a warm one. However, while in winter the circulations from SW, W and NW directions constitute warm advection, in summer the following directions: from $\mathrm{W}$ through NW to $\mathrm{N}$ are evidently cold advections. This results from the physical properties that a given air mass acquired above the source area. In winter NE direction brings the coldest air on all isobaric surfaces. Whereas in summer the same situation is caused by NW direction. While in summer four directions, i.e.: $E, S E, S$ and $S W$, are mainly responsible for the advection of warm air masses, in summer the warming effect of SW direction is distinctly weaker than it is in winter or throughout the year.

4. When analysing both components of circulation (direction and kind) together, it can be observed that throughout the year as well as in winter and in summer isobaric surfaces are located at the lowest levels during the circulations from the northern quadrant. These situations are accompanied by the lowest temperatures of the 
analysed surfaces. These are cold circulations. Warm air inflows during the circulations from the following directions: from E through $S$ to $W$, especially from SW and W (Figs. 5, 6). Annually, cyclonic situations are warmer than anticyclonic during eastern advection, whereas during the advection from the west anticyclonic circulations are warmer than cyclonic ones.

5. Northern circulations exert a stronger influence on atmospheric temperature than the southern ones. It is a rule that all isobaric surfaces, regardless of the direction of circulation, are located at the lower levels during cyclonic circulation than during anticyclonic one.

6. Atmospheric circulation plays a significant role in shaping troposphere temperature conditions.

The relationships that have been recognised in the study basing on a relatively long period of aerological measurements give grounds to determine the - important for climatology - average meteorological parameters on the vertical axis of atmosphere. They are consistent with the previous results of the studies on atmospheric circulation's impact on the temperatures above Poland and Europe. They can not only be employed to forecast the weather, but also give rise

\section{References}

Asnani G.C., Mishra S.K., 1975. Annual preasure oscillation from sea-level to $100 \mathrm{mb}$ in the Northen Hemisphere. International Journal of Meteorology Hydrology and Geophysics, vol. 26, pp. 355-361.

BARTOSZEK K., 2017. The main characteristics of atmospheric circulation over East-Central Europe from 1871 to 2010. Meteorology and Atmospheric Physics, vol. 129, no. 2, pp. 113129.

BĄKOWskI R., 2003. Cyrkulacja dolnotroposferyczna na obszarze Karpat Polskich. Wiadomości IMGW, vol. 26, no. 4, pp. 3-38. to a research aspect with regard to climate changes, etc. The universality of the circulation calendar which was used and the geographical location of the Aerological Station in Legionowo entitle us to claim the results of this study to be representative for the lowland of Central Europe in the context of, for example, the changes of the temperatures of isobaric surfaces in troposphere. Nonetheless, in order to render the investigation of their changeability and statistical significance possible, these results require a further research which would be based on a greater number of stations and conducted for a longer time.

\section{Acknowledgments}

The authors would like to thank the anonymous Reviewers for their valuable comments and suggestions to improve the quality of the paper.

\section{Editors' note:}

Unless otherwise stated, the sources of tables and figures are the authors', on the basis of their own research.

BĄKOWSKI R., 2007. Wpływ adwekcyjnych zmian temperatury w swobodnej atmosferze na zmiany temperatury powietrza przy powierzchni ziemi w Krakowie [in:] K. Piotrowicz, R. Twardosz (eds.), Wahania klimatu w różnych skalach przestrzennych i czasowych, Kraków: Instytut Geografii i Gospodarki Przestrzennej, Uniwersytet Jagielloński, pp. 245-252.

Biszczuk-Jakubowska E., ZabŁocki G., 2015. Pomiary aerologiczne w Polsce. Gazeta Obserwatora IMGW, vol. 64, no. 1, pp. 19-23.

Buishand T.A., Brandsma T., 1997. Comparison of circulation classification schemes for predicting temperature and precipitation in the Netherlands. International Journal of Climatology, vol. 17, pp. 875-889. 
Degirmendžlć J., 2003. Sezonowe zmiany przestrzennej struktury adwekcji ciepła i chłodu na powierzchni izobarycznej 850 hPa nad Polska. Czasopismo Geograficzne, vol. 74, no. 1-2, pp. 107-117.

Degirmendžıć J., KożUChowskı K., 2017. Makrocyrkulacyjne uwarunkowania długotrwałych fal termicznych w Polsce. Przegląd Geofizyczny, vol. 62, no. 1-2, pp. 3-28.

Hess M., 1965. Piętra klimatyczne w polskich Karpatach Zachodnich. Zeszyty Naukowe UJ, Prace Geograficzne, vol. 11, Kraków: Uniwersytet Jagielloński.

Hess M., Niedźwiedź T., Obręika-Starklowa B., 1980. O prawidłowościach piętrowego zróżnicowania stosunków klimatycznych w Sudetach. Rocznik Naukowo-Dydaktyczny Wyższej Szkoły Pedagogicznej w Krakowie, vol. 71, pp. 167-201.

Hill A.E., Simpson J.H., 1989. On the interaction of thermal and haline fronts: The Islay Front Revisited. Estuarine Coastal and Shelf Science, vol. 28, no. 5, pp. 495-505.

Huang J., van den Dool H.M., Barnston A.G., 1996. Long-lead seasonal temperature prediction using optimal climate normals. Journal of Climate, vol. 9, no. 4, pp. 809-817.

Huth R., Beck C., Philipp A., Demuzere M., Ustrnul Z., Cahynová M., Kyselý J., TVelTO O.E., 2008. Classifications of atmospheric circulation patterns recent advances and applications. Annals of the New York Academy of Sciences, vol. 1146, no. 1, pp. 105-152.

Japan Meteorological Agency, 1988. On the improvement of the significant weather chart. Weather Service Bulletin, vol. 55, pp. 1-16.

Kalnay E., Kanamitsu R., Kistler R., Collins W., Deaven D., Gandin L., Iredell M., Saha S., White G., Woolen J., Zhu Y., Chelliah M., Ebisuzaki W., Higgins W., Janowiak J., Mo K.C., Ropelewski C., Wang J., LeetmaA A., Reynolds R., Jenne R., Joseph D., 1996. The NCEP/ NCAR 40-year reanalysis project. Bulletin of American Meteorological Society, vol. 77, pp. 437-471.

KAsZEWskI B.M., 2012. Zastosowanie typologii cyrkulacji atmosfery $w$ badaniach klimatologicznych w Polsce na poczatku XXI wieku [in:] Z. Bielec-Bąowska, E. Łupikasza, A. Widawski (ed.), Rola cyrkulacji atmosfery w kształtowaniu klimatu, Prace Wydziału Nauk o Ziemi Uniwersytetu Ślaskiego, vol. 74, pp. 53-66.
KoWALEWSKI M., 2003. Zmienność położenia tropopauzy w wysokich szerokościach geograficznych. Problemy Klimatologii Polarnej, vol. 13, pp. 37-41.

KożUchowski K., Wibig J., Maheras P., 1992. Connections between air temperature and precipitation and the geopotential height of the $500 \mathrm{hPa}$ level in a meridional cross-section in Europe. International Journal of Climatology, vol. 12, no. 4, pp. 343-352.

KULESZA K., 2017. Nowe spojrzenie na klasyfikacje typów cyrkulacji atmosfery J. Lityńskiego. Prace Geograficzne, no. 150, Instytut Geografii i Gospodarki Przestrzennej UJ, Wydawnictwo Uniwersytetu Jagiellońskiego, pp. 79-94.

KYSELÝ J., 2002. Temporal fluctuations in heat waves at Prague-Klementinum, the Czech Republic, from 1901-97, and their relationships to atmospheric circulation. International Journal of Climatology, vol. 22, no. 1, pp. 33-50.

KYSELÝ J., HUtH R., 2006. Changes in atmospheric circulation over Europe detected by objective and subjective methods. Theoretical and Applied Climatology, vol. 85, no. 1-2, pp. 19-36.

LITYŃSKI J., 1968. Liczbowa klasyfikacja typów cyrkulacji i typów pogody dla Polski. University of Warsaw [PhD thesis, typescript].

LITYŃSKI J., 1969. Liczbowa klasyfikacja typów cyrkulacji i typów pogody dla Polski. Prace Państwowego Instytutu Hydrologiczno-Meteorologicznego, vol. 97, pp. 3-15.

ŁUPIKASZA E., 2010. Relationships between occurrence of high precipitation and atmospheric circulation in Poland using different classifications of circulation types. Physics and Chemistry of the Earth, vol. 35, no. 9-12, pp. 448-455.

Marshall G.J., 2002. Analysis of recent circulation and thermal advection in the northern Antarctic Peninsula. International Journal of Climatology, vol. 22, no. 12, pp. 1557-1567.

Niedźwiedź T., 1981. Sytuacje synoptyczne $i$ ich wpływ na zróżnicowanie przestrzenne wybranych elementów klimatycznych $w$ dorzeczu górnej Wisły. Rozprawy Habilitacyjne, vol. 58, Kraków: Uniwersytet Jagielloński.

NiedźWiedź T., 2000. Dynamics to selected extreme climatic events in Poland. Geographia Polonica, vol. 73, no. 2, pp. 25-39.

Nowosad M., 2004. Sezony cyrkulacyjne nad Polska 1951-1990. Annales Universitatis Mariae 
Curie-Skłodowska. Sectio B, vol. 59, no. 5, pp. 83-100.

OJRZYŃSKA H., 2012. Obiektywny kalendarz cyrkulacji atmosferycznej dla Sudetów - założenia i metody konstrukcji oparte na systemie GRASS. Przeglad Geofizyczny, vol. 57, no. 2, pp. 17-29.

Ordakowski H., Stefanicki K., Kowalska D., 2000. Klucze aerologiczne. Instrukcja szyfrowania wyników pomiarów aerologicznych. Warszawa: Instytut Meteorologii i Gospodarki Wodnej.

PawŁowska J., Jankowska A., Pindor T., 2000. Kalendarz typów cyrkulacji atmosferycznej według J. Lityńskiego (1991-1999). Warszawa: Instytut Meteorologii i Gospodarki Wodnej.

Philipp A., Bartholy J., Beck Ch., Erpicum M., Esteban P., Fettweis $X$. , Huth R., James P., Jourdain $S$., Kreienkamp F., Krennert T., Lykoudis $S$., Michalides S.C., Pianko-KluCZYŃSKa K., Postm P., Rasilla Álvarez D., Schiemann R., SpekAt A., Tymvios F.S., 2010. Cost733cat - A database of weather and circulation type classifications. Physics and Chemistry of the Earth, vol. 35, no. 9-12, pp. 360-373.

PianKo-KluczyńsKa K., 2007. Nowy kalendarz typów cyrkulacji atmosfery według J. Lityńskiego. Wiadomości Meteorologii Hydrologi i Gospodarki Wodnej, vol. 1, no 4, pp. 65-85.

Plaut G., Simonnet E., 2001. Large-scale circulation classification, weather regimes, and local climate over France, the Alps and Western Europe. Climate Research, vol. 17, no. 3, pp. 303-324.

PYKA J.L., 1990. Zmienność pola barycznego i termicznego swobodnej atmosfery nad Europa $w$ latach 1961-1985. Acta Universitatis Wratislaviensis, no. 1275, Studia Geograficzne, vol. 55, Wrocław: Wydawnictwa Uniwersytetu Wrocławskiego.

Renard R.J., Clark L.C., 1965. Experiments in numerical objective frontal analysis. Monthly Weather Review, vol. 93, pp. 547-556.

Sepp M., JaAgus J., 2002. Frequency of circulation patterns and air temperature variations in Europe. Boreal Environment Research, vol. 7, pp. 273-279.

SEWERYŃSKA H., 1978. Zwiqzek między polem geopotencjału powierzchni $500 \mathrm{mb}$ a temperatura w Polsce. Materiały Badawcze IMGW. Seria Meteorologia, vol. 3, Warszawa: Instytut Meteorologii i Gospodarki Wodnej - Państwowy Instytut Badawczy.
Strauch A., 1974. Przebieg temperatury w troposferze nad Polska Środkowa w różnych masach powietrza. Materiały Badawcze IMGW. Seria Meteorologia, vol. 1, Warszawa: Instytut Meteorologii i Gospodarki Wodnej - Państwowy Instytut Badawczy.

ThornCROFt C.D., Hoskins B.J., 1990. Frontal cyclogenesis. Journal of the Atmospheric Sciences, vol. 47, no. 19, pp. 2317-2336.

Tomczyk A.M., Bednorz E., 2016. Heat waves in Central Europe and their circulation conditions. International Journal of Climatology, vol. 36, no. 2, pp. 770-782.

Tomczyk A.M., Bednorz E., Pótrolniczak M., Kolendowicz L., 2018. Strong heat and cold waves in Poland in relation with the largescale atmospheric circulation. Theoretical and Applied Climatology, pp. 1-15.

Urban G., Richterová D., Kliegrová S., ZuskoVÁ I., PAwliczek P., 2018. Winter severity and snowiness and their multiannual variability in the Karkonosze Mountains and Jizera Mountains. Theoretical and Applied Climatology, vol. 134, no. 2, pp. 221-240.

Ustrnul Z., Czekierda D., Wypych A., 2010. Extreme values of air temperature in Poland according to different atmospheric circulation classifications. Physics and Chemistry of the Earth, Parts $A / B / C$, vol. 35, no. 9-12, pp. 429-436.

UstrnUL Z., WYPYCH A., 2011. Ekstremalne wartości temperatury powietrza w Polsce w świetle różnych klasyfikacji typów cyrkulacji. Prace i Studia Geograficzne, vol. 47, pp. 87-95.

Ustrnul Z., Wypych A., Winkler J.A., CzeKIERDA D., 2014. Late spring freezes in Poland in relation to atmospheric circulation. Quaestiones Geographicae, vol. 33, no. 3, Poznań: Bogucki Wydawnictwo Naukowe, pp. 165-172.

WIBIG J., 1994. Wpływ cyrkulacji na powierzchni izobarycznej $500 \mathrm{hPa}$ na temperature powietrza w Polsce. Przegląd Geofizyczny, vol. 39, no. 2, pp. 133-150.

WIBIG J., 2001. Wpływ cyrkulacji atmosferycznej na rozkład przestrzenny anomalii temperatury i opadów w Europie. Łódź: Wydawnictwo Uniwersytetu Łódzkiego.

Wibig J., Podstawczyńska A., Rzepa M., PiotrowsKI P., 2009a. Heat waves in Poland - frequency, trends and relationships with atmospheric 
circulation. Geographia Polonica, vol. 82, no. 1, pp. 33-46.

Wibig J., Podstawczyńska A., Rzepa M., PiotrowsKI P., 2009b. Cold waves in Poland - frequency, trends and relationships with atmospheric circulation. Geographia Polonica, vol. 82, no. 1, pp. 47-59.

ŻMUDZKA E., 2007. Zmienność zachmurzenia nad Polska i jej uwarunkowania cyrkulacyjne (19512000). Warszawa: Wydawnictwo Uniwersytetu Warszawskiego. 